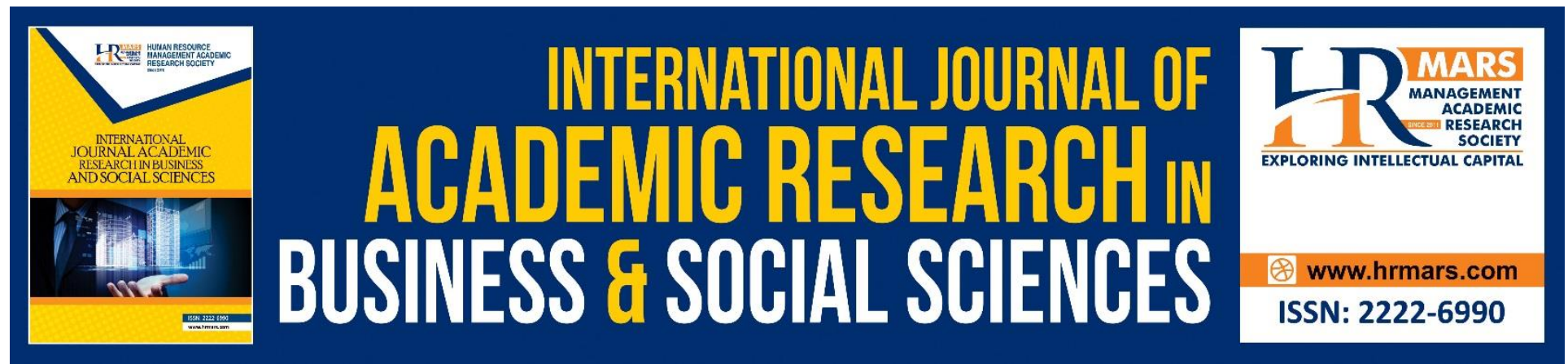

\title{
An Evaluation of Four-Decade Experience of Industrial Policy in Sri Lanka: 1977-2017
}

\section{Wasantha Rajapakshe}

To Link this Article: http://dx.doi.org/10.6007/IJARBSS/v8-i12/5139

DOI: $10.6007 /$ IJARBSS/v8-i12/5139

Received: 30 Nov 2018, Revised: 13 Dec 2018, Accepted: 25 Dec 2018

Published Online: 29 Dec 2018

In-Text Citation: (Rajapakshe, 2018)

To Cite this Article: Rajapakshe, W. (2018). An Evaluation of Four-Decade Experience of Industrial Policy in Sri Lanka: 1977-2017. International Journal of Academic Research in Business and Social Sciences, 8(12), 969986.

\section{Copyright: (C) 2018 The Author(s)}

Published by Human Resource Management Academic Research Society (www.hrmars.com)

This article is published under the Creative Commons Attribution (CC BY 4.0) license. Anyone may reproduce, distribute, translate and create derivative works of this article (for both commercial and non-commercial purposes), subject to full attribution to the original publication and authors. The full terms of this license may be seen

at: http://creativecommons.org/licences/by/4.0/legalcode

Vol. 8, No. 12, 2018, Pg. 969 - 986

http://hrmars.com/index.php/pages/detail/IJARBSS

JOURNAL HOMEPAGE

Full Terms \& Conditions of access and use can be found at http://hrmars.com/index.php/pages/detail/publication-ethics 


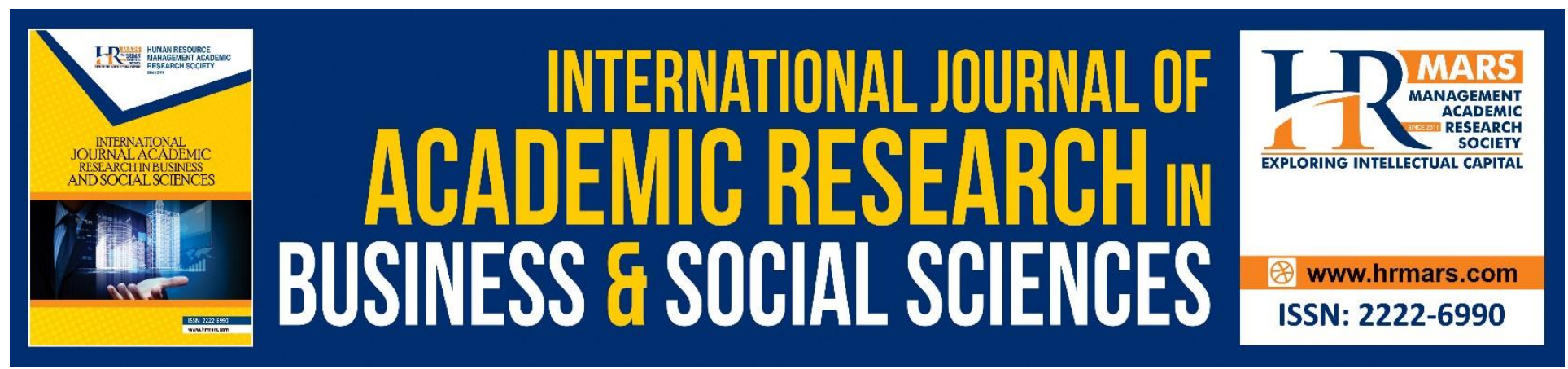

\title{
An Evaluation of Four-Decade Experience of Industrial Policy in Sri Lanka: 1977-2017
}

\author{
Wasantha Rajapakshe \\ Senior Lecturer (Higher Grade), SLIIT Business School, Sri Lanka Institute of Information \\ Technology, Sri Lanka \\ Email: wasantha.r@sliit.lk
}

\begin{abstract}
The objective of this study is to explain four decades of experience regarding export expansion under the new industrial policy, which was introduced in 1977 in Sri Lanka. The industrial policy has multiple objectives however the study was limited to export expansion and industrial sector achievements. This research is primarily based on secondary data and involves an extensive literature review on the area of concern to provide an overview of the industry policy and economic impact of Sri Lanka. The study presents the current status of industrial policy and highlights the contemporary issues in industrial policy in Sri Lankan economic development during four decade start from 1977 up to 2017. It is concluded that after four decades of experience, Sri Lanka is achieved moderate growth even though unable to maintain the required growth rate to make Sri Lanka as a fast growing economy in South Asia. Sri Lanka has opportunity to grow faster than other South Asian countries because of long term welfarism of the country for free health and education, already made talented and healthiest citizen comparing other South Asian countries.

Keywords: Industrial Policy, Industrial Sector, Export Expansion, Policy Stakeholders, Policy Environment

\section{INTRODUCTION}

The purpose of this paper is to explain in four decades of experience regarding export expansion under the industrial policy, which was introduced in 1977 in Sri Lanka. Since in early 1960 s' $^{\prime}$ as in most other developing countries, the dominant government policy in Sri Lanka was state led import substitution industrial policy. In order to help these important substitution industries, Sri Lankan government had state intervention and controls, heavy tariffs for imports, quantitative restrictions, import bans and licensing. The heavy industries like steel, sugar cement, paper etc. as well as public transportation were to be developed as state corporations. However, this inward industrial policy made many issues like poor quality of the product, state
\end{abstract}


sector over staffing, poor management and lack of incentives for expansion, leading to losses and subsidization of state enterprises (Bruton, 1992:119-147).

In 1977, new government who came into power introduced economic liberalization policy with allowing private sector to enter into industry. In addition in this stage, liberalization trade, removal tariff and quantity barriers were major changes came under in this policy. In the second stage in 1989/1990, under this policy abandonment of approval requirements for establishing industries, liberalization of the foreign investment was granted under the Board of Investment (BOI) in Sri Lanka as well as privatized state owned industries (Athukorala \& Jayasuriya, 1994:2024). In the third stage Sri Lanka adopted Article VIII Status of the International Monetary Fund (IMF) freeing all foreign exchange transactions on the current account (Central Bank of Sri Lanka, 1997:61). After then many successive government came into power, however, in keeping with the world wide trends, the liberalization policies were continued with minor changes. They pursued the efforts of removal of nontariff barrier, reduction of tariff and pursuit of the program of privatization and played more active rather than passive role in relation to industrial policy (Central Bank of Sri Lanka, 2017).

\section{THE INDUSTRIAL POLICY IN SRI LANKA}

Industrial policy in Sri Lanka introduced in 1977 considered strengthening the private sector led export oriented industrialization strategy. As the industrial policy recognized the private sectors as the engine of growth, their participation in formulation and implementation of policies relating to the industrial sector was encouraged. In this respect, Development Review Committee as an Advisory Council for industry was established. These committees consisting of experienced officials from the public sector, private sector and research institutes were entrusted with the responsibility of policy formulation, indicative planning, problem solving and advising the government, work programming, reviewing the program of existing policies and recommending new policy changes.

A Presidential Trade and Tariff Commission (PTTC) was established during 1997 to further rationalize the tariff structure and look into matters affecting the existence and expansion of domestic manufacturing industries (Central Bank of Sri Lanka, 1997:61). In addition, in 1995 National Productivity Decade was introduced and the National Secretariat was established to improve national productivity. During this period industrial policy in Sri Lanka focus on labor intensive industries as well as technology intensive industries. In addition, Skills Development Fund was formed to provide training programs for laborers. The government who came to power in 2004 also continued same industrial policy with minor changes. In this period national Council for Economic Development was established to improve competitiveness of several important industries like, garment, ceramics, gem and jewelry, etc. In addition, 12 new industrial investment zones were established in 12 urban areas. Moreover, development policy in this era was encouraged domestic industrialists especially export-oriented industries (Institute of Policy Studies of Sri Lanka, 2012).

The nature of industrial policy has generally reflected the importance placed on industrial development and expectations to enter to the international market. All successive governments after 1997 have followed and practiced same strategies with minor changes. After four decade from 1977 up to 2017, is Sri Lanka achieved the above said objectives? Hence, the objective of this paper is to analyze ultimate result of this industrialization policy after four decades of 
continuity. Even though the industrial policy has multiple objectives, the study was limited to export expansion and industrial sector achievements.

\section{METHODOLOGY}

This research is primarily based on secondary data and involves an extensive literature review on the area of concern to provide an overview of the industrial policy and economic impact of Sri Lanka. Therefore data collected from various published sources such as central bank reports in Sri Lanka, various annual reports, relevant books, peer journals, and also current electronic publications (valid websites). The study presents the current status of industrial policy and highlights the contemporary issues in industrial policy in Sri Lankan economic development during four decade start from 1977 up to 2017.

\section{EVALUATION OF INDUSTRIAL POLICY IN SRI LANKA}

'Public policy' is defined by many scholars. Dye (1978) defined "Public policy as 'anything a government chooses to do or not to do'." According to this clarification government is the primary agent and other interest group are not in the decision making process. This definition also highlighted that public policy is a choice of government. Dye emphasized on government action, as well as on government inaction. Therefore, his definition indicates the character of behaviorism. Dye's three elements model are fundamental to understanding public policy as an applied problem-solving process. When government make policies it is always based on a number of decisions that together contribute to an ultimate policy.

For the purpose of this study, Dye's three elements of the policy system model were applied to determine how industrial policy was influenced by policy stakeholders and policy environment. According to the Dye's (1978) framework following factors was identified as policy environment related to the industrial policy in Sri Lanka and as most prominent policy stakeholders who influenced to develop new industrial policy in Sri Lanka (Central Bank of Sri Lanka, 1997- 2017; BOI Reports, 1997-2017). 


\section{Policy Environment}

Employment in Rural and Urban Sectors,

Export Orientation,

Regional Industrialization,

Efficient Management,

Man Power Resources,

Sustainable Development, International Competitiveness,

Foreign Investment Promotion,

Macro-Economic Policy Framework,

Infrastructure Development,

Regional Industrialization,

Small and Medium Industry Sector Development,

Productivity Improvement.

\section{Policy Stakeholders}

Export Development Board, Ministry of Industrial Development,

Private Sector Industries,

Foreign Investors,

Local Industrial Estates,

Urban Development Authority,

Trade Unions,

Skill Development Fund,

Export Oriented Garment Industry,

Textile Debt Recovery Fund,

Domestic Textile Allocation Committee,

Political Parties,

International Monetary Funds,

Development Review Committee,

Presidential Trade and Tariff Commission,

Central Bank of Sri Lanka, Employers,

Unemployed,

Schools and Higher Educational Institutions,

General Public. 
Figure 01: Three Elements of Policy System

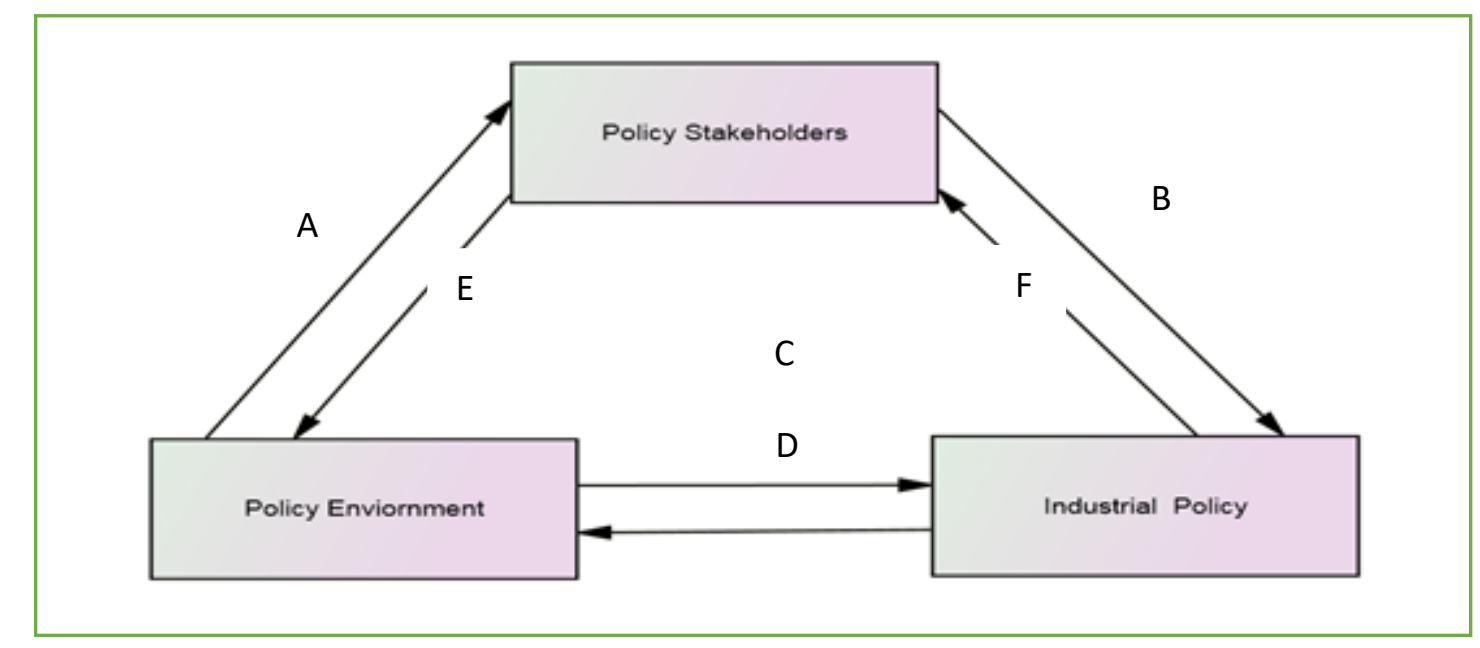

Export Promotion and International Competitiveness: One of the major influences of the society was to raise export oriented industries in the context of globalization. The Export Development Board (EDB) in Sri Lanka directly requested to take a lead role in export promotion with the collaboration of Ministry of Industrial Development. The need to assist local industries to be internationally competitive was an important request (UNIDO, 1995:28-32; Asian Development Bank, 2017:13).

Macro-Economic Policy Framework: Another major influence was macro- economic stability. Among the key areas of this overall framework, the reduction of budget deficit, reduction of inflation, lower the interest rate and lower a tax and tariff were more highlighted (UNIDO, 1995:28-32; Asian Development Bank, 2017:19).

Efficient Management of Physical and Manpower Resources: The man power development was recognized as an important aspect of industrial development in 1977. Even though there were many training institutions, skill development remains in a dark in the industrial sector. Because of the influences, Sri Lanka setup a Skills Development Funds with the participation of the private sector and with donor assistance to promote a demand driven skills development programs (UNIDO, 1995:28-32; Asian Development Bank, 2017:268).

\section{LINKAGE B: The Effect of Policy Stake Holders on Industrial Policy}

Request to Develop Infrastructure: The lacks of adequate infrastructure were identified as one of the main crisis of industrial development. This is mainly consists with transportation, communication and power. In 1977, under the new policy it was tried to correct these inadequacies (Widyantha, 1997:2-3).

Small and Medium Industry Sector and Regional Industrialization: Alongside with the 1977 policy, industrial estates, parks and townships were developed with the objective of facilitating industrialists through common facilities, alleviating environmental problems, and ensuring industrial solution. In addition, Industrial Development Board in Sri Lanka made direct efforts to areas such as 
INTERNATIONAL JOURNAL OF ACADEMIC RESEARCH IN BUSINESS AND SOCIAL SCIENCES Vol. 8, No. 12, Dec, 2018, E-ISSN: 2222-6990 @ 2018 HRMARS

access to funds, entrepreneur development, infusion of technology, product improvement skills training and local and foreign marketing (UNIDO, 1995:38-43; World Bank, 2016:34-38).

Optimize and Maximize the Usage of Local Raw Materials: Unlike japan or Singapore, Sri Lanka need not depend on other countries for sourcing all the raw materials. The main argument of the Central bank of Sri Lanka was Sri Lanka has to cover up the raw material requirement locally to compete with other countries. The industrial policy therefore included some restrictions related to the import of raw material (Widyantha, 1997:2-3).

Invest in fast Developing Communication Technology: Another requirement was revolution of communication technology by modernizing internet and better telephone facilities. The main argument was they could provide the industrialist with more information and a greater access to the market (Widyantha, 1997:2-3).

Establishment and Implementation of Zonal Policy: To provide basic infrastructure facilities, the industrial policy led to established free trade zone in urban as well as rural areas. This was one of the major issues raised by the stakeholders to acquire basic facilities like land, building etc. (Rajapakshe, 2018).

LINKAGE C: The Effect of Policy Environment on Industrial Policy

Problems of Unemployment and Income Generation in both Rural and Urban Sectors: In early 1977, unemployment rate in Sri Lanka was 16.4 per cent and GNP per capita income was \$297 (World Bank, 1984:45). Therefore an industrial sector was seen as the main mechanism to raise employment and income in Sri Lanka (Widyantha, 1997:2-3; World Bank, 2016:14-15; Export Development Board, 2016).

Global Trend for Export Orientation: The adverse impact of inward looking import substitution policy encouraged the industry to be export oriented. Today in terms of the globalization and free trade industry also has led to be competitive and export oriented. Therefore, in Sri Lanka also looking forward export oriented economic as well as industry and service sector as better strategy for growth (Widyantha, 1997:2-3; Athukorala, 2014).

Lack of Regional Industrialization: Another important influence was the promotion of regional industrialization. Dispersal of industries to the regimes is a necessary development both from the interests of industry and of regional development and improvement of rural income (Widyantha, 1997:2-3; Athukorala, 2014; Export Development Board, 2016).

Need of Sustainable Development: The industrial policy was also requested to aim at the fostering of environmental friendly and sustainable development. Increasing emphasis was being placed the world over on environmental concerns and the harmonization of developmental and environmental concerns today constitute one of the main objectives of industrial policy in any country today (Widyantha, 1997:2-3; Asian Development Bank, 2017; Export Development Board, 2016).

\section{LINKAGE D: The Feedback of Industrial Policy on Policy Stake Holders}

Private Sector Orientation: Industry policy in Sri Lanka today identifies private sector as the engine of economic growth, in keeping with current global trends. It constitutes a further movement away from state intervention and controls. It focuses on gearing the agencies of government for facilitation and promotion of industries. Further, maintaining a continuous formal as well as less 
INTERNATIONAL JOURNAL OF ACADEMIC RESEARCH IN BUSINESS AND SOCIAL SCIENCES

Vol. 8, No. 12, Dec, 2018, E-ISSN: 2222-6990 @ 2018 HRMARS

formal communications with private sector industrialists and their chambers and federations (Export Development Board, 2016).

\section{LINKAGE E: The Effect of Policy Stake Holders on Policy Environment}

Foreign Investment Promotion: One of the major feedbacks from the industrial policy through stakeholders was foreign investment promotions. The country's low rate of savings leads to urgent foreign direct investment. The Ministry of Industrial Development assists the Board of Investment (BOI), the main agency for investment promotion, serving as a one stop service sector for investors. In addition, BOO-BOT that is Build Operate \& Own and Build Operate \& Transfer system was introduced to promote investments in Sri Lanka ( Widyantha, 1997).

\section{LINKAGE F: The Feedback of Public Policies on Stake Holders}

Provision of Regular Training and Exposure to Modern Technology: This was another important aspect taken into consideration as results of employers as well as employees demand. Now, regular programs are conducted by many higher Educational institutes particularly in the area of productivity, quality and human resources.

Productivity Improvement: Current competitiveness in international markets recognizes employee productivity as key elements for attracting foreign investors. Quality improvement considers as consequences for increase employees' productivity. Thus, as in other countries, awareness program would support to improve quality and productivity. This has to be directed to different categories like society, work place, unions, employers, students, homes and general public (UNIDO, 1995:28-32).

Incentives provide to the industrial sector for export promotion: The government continued to provide incentives to both foreign and domestic investors in order to achieve the objectives of the industrial policy. Although in the past most incentives were especially provided to $\mathrm{BO}$ enterprises, but later extend these incentives to non-BOI enterprises recognizing the need to gradually move towards equalizing the incentives between the $\mathrm{BO}$ and non-BOI sectors and expand export oriented industries (Central Bank of Sri Lanka, 1997, 61-63; Export Development Board, 2016).

Incentives for Apparel Sector: High tariffs, taxes and other levies on imported textiles and related materials and various custom procedures have caused difficulties to apparel sectors manufacturers who heavily rely on imported raw materials. In 1996, government has eliminated duties on imported raw materials. In addition, a special fund known as Textile Debt Recovery Fund (TDRF) was setup to transfer all outstanding loans together with accrued interest. A Domestic Textile Allocation Committee was setup to assess the fabric requirement of government institutions and identify the manufacturers to whom the allocation would be made on a quota basis (Central Bank of SL, 1997:61-63). In addition, in 2017 budget speech, proposed a backward integration and produced fabric dyeing and finishing unit (Ministry of Finance Sri Lanka, 2016:40). Moreover, permission has given to import branded product and rework them and export back (Ministry of Finance Sri Lanka, 2016:40). In 2017, Sri Lankan government in the budget proposal provides more incentives. Apparel companies can invest up to $5 \%$ of their turnover in a foreign apparel industry and received profit (Ministry of Finance Sri Lanka, 2016:37). In addition, introduce fashion design as a new subject to 
school curricular and established 15 export villages some are related with apparel industry (Ministry of Finance Sri Lanka, 2016:40).

Incentives for Electronic Industry Sector: Electronics and components for electronic assembling, ceramics and glass ware, and rubber based industries, light and heavy engineering, cutting and polishing of gems, diamonds and manufacturing of jewelry has identified as "trust industries" to attract investment. A series of incentives was announced by government for the sector including exemption from income tax and national security levy and duty free import of gems and gold (Central Bank of Sri Lanka, 1997:61-63). In 2017, the sectoral strategy under the National Export Strategy (NES) was endorsed and budgeted by the government of Sri Lanka to provide a focused path for the sector to move forward in a way similar to this sector in other countries in the region that have the support of their government. The endorsement of and budget for this strategy provide the support to guide the sector towards strategic growth in terms of technology, investments and employment generation (Central Bank of Sri Lanka, 2016; Government of Sri Lanka, 2018).

Analysis of the Industrial Sector Development: Thus far Sri Lanka has responded reasonably well to the industrial policies adopted over the last four decades. For the purpose of this study following three major changes and improvement were analyzed; (1) changes in the sectoral composition; (2) economic growth and (3) export expansion (Central bank of Sri Lanka, 1997: 61-63; Export Development Board, 2016).

Incentives for Regional Development: For developing the remote areas, the government introduced a new incentive structure. Accordingly, any $\mathrm{BO}$ or non-BOI enterprises in commercial operation would be entitled to receive incentives offered by BOI. There benefits are eligible for enterprises, which are already located in rural areas for expansion at the same location (Central bank of Sri Lanka: 1997, 61-63; Export Development Board, 2016).

Incentive for Productivity Development: The government identifies labor as a significant factor for determines production cost and quality. Proper labor management can lead to reduce unit cost labor by improving productivity in order to maintain international competitiveness. For the purpose of this, the year 1996 was declared as the "year of productivity" and the period from 1997 to 2006 has been declared as the "Decade of productivity" (Central bank of Sri Lanka: 1997).

\section{CHANGES IN THE SECTORAL COMPOSITION: 1977-2017}

This section is presented Sri Lanka experience of the industrial sector changes and composition during last four decade. 
INTERNATIONAL JOURNAL OF ACADEMIC RESEARCH IN BUSINESS AND SOCIAL SCIENCES Vol. 8, No. 12, Dec, 2018, E-ISSN: 2222-6990 @ 2018 HRMARS

Figure 02: Gross National Product (GNP) (Sector shares in percent)

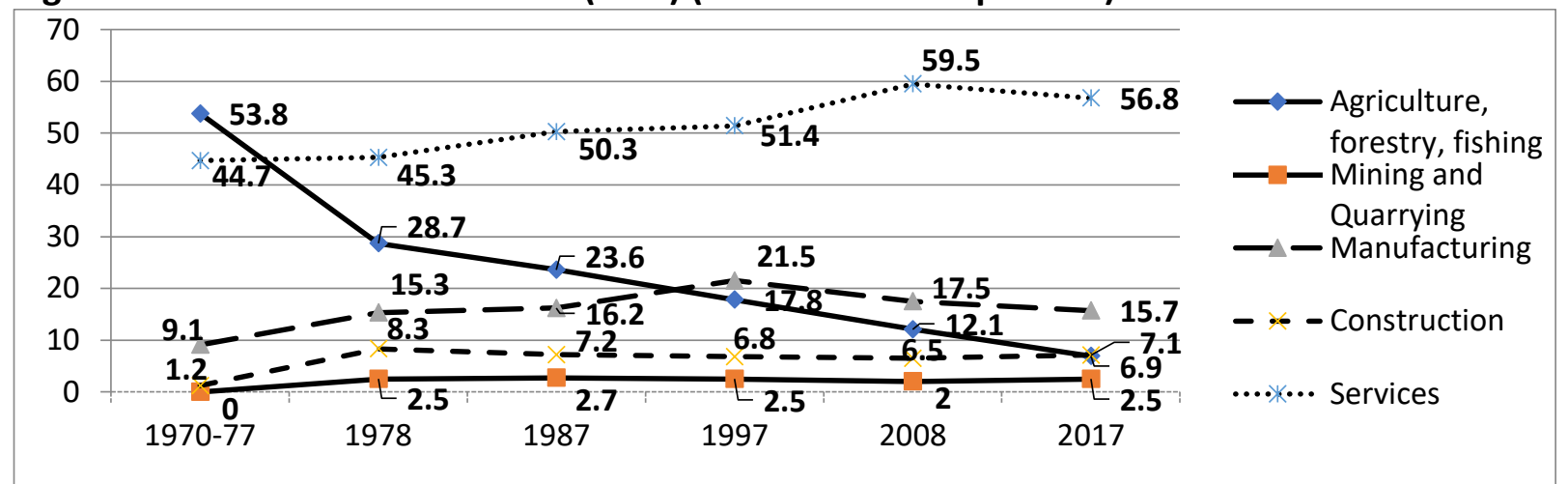

Source: Athukorala \& Jayasuriya, 1994; Central Bank of Sri Lanka (CBSL), 1997; CBSL 2008; CBSL 2017 As shown in Figure 02, in 1970-77 agriculture sector was share 53.8 percent to GNP while manufacturing sector was 9.1 percent and a service sector was 44.7 percent. After 1977 with new economic liberalization policy, it was gradually change and in 2017 agriculture sector became 6.9 percent while manufacturing sector contribution was increased to 15.7 percent and service sector was increased to 56.8 percent.

Figure 03: GNP Sectoral Growth Rate (\%)

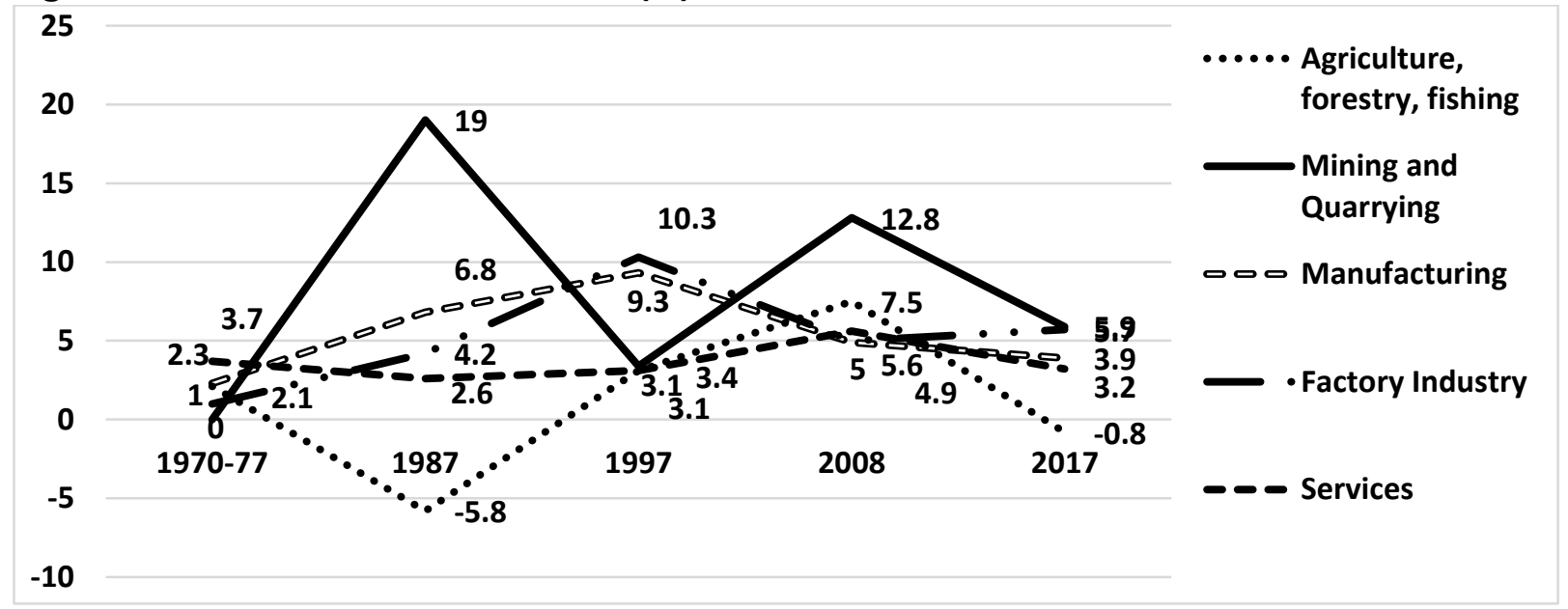

Source: Athukorala \& Jayasuriya, 1994; CBSL, 1997; CBSL 2008; CBSL 2017

GNP sectoral growth rates were shown in Figure 03. As the time of independence, Sri Lanka economy was heavily dependent on limited agricultural export commodities. After introducing the new economic liberalization policy this sectoral composition swapped gradually. In 1987, agriculture sector's growth was -5.8 while mining and quarrying was increased to 19.0 percent and manufacturing became 6.8 percent. Moreover, in 1997 manufacturing sector was grown up to 9.3 percent and factory industry sub sector growth rate increased to 10.3 percent and became the largest sector which had a massive impact on Sri Lankan economy. However, in 2017 it was reduced to 5.7. 
INTERNATIONAL JOURNAL OF ACADEMIC RESEARCH IN BUSINESS AND SOCIAL SCIENCES Vol. 8, No. 12, Dec, 2018, E-ISSN: 2222-6990 @ 2018 HRMARS

Figure 04: Changes in Export Composition as a \% of Total Export- 1977-2017

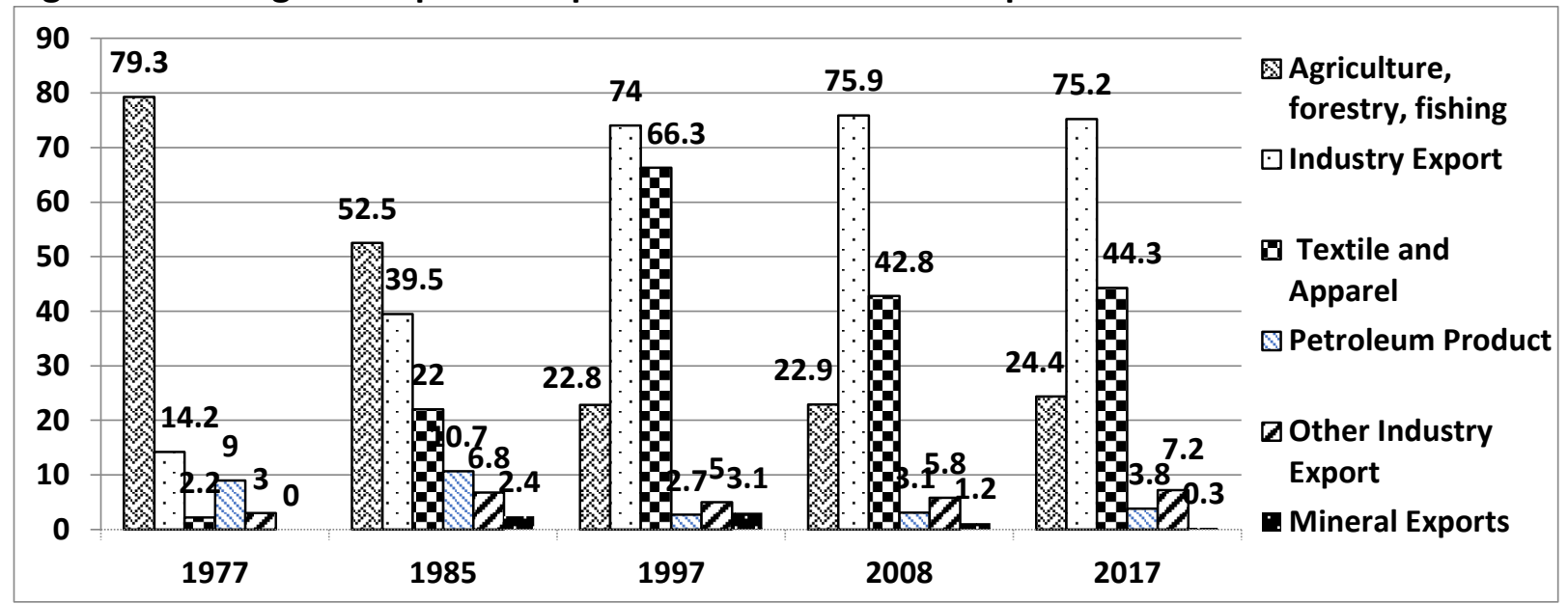

Source: Athukorala \& Jayasuriya, 1994; CBSL, 1997; CBSL 2008; CBSL 2017

Figure 04 shows changes in export composition as a percent of total exports from 1977-2017. The indicators of export promotion in Sri Lanka show a quite optimistic picture of the performance. The most significant achievement in terms of export promotion after 1977 was changes in the composition of the export structure, which was dominated by agriculture to that dominated by manufacturing sector. In 2017 total industrial export had increased to 75.2 percent from 14.2 percent in 1977. In contrast, agriculture exports were decreased to 24.4 in 2017 from 79.3 percent in 1977. Meanwhile largest sub sector of industrial export became textile and apparel shows massive changes. Textile and apparel export was grown to 44.3 percent in 2017 from 2.2 percent in 1977. The export share of other industrial products was also being expanding slower rate from 3.0 percent in 1977 to 7.2 percent in 2017. Simultaneously, the export share of petroleum product, which at 9 percent in 1977 was the largest single manufacturing export item, was declined to 3.8 percent in 2017.

Figure 05: Changes in Export as a \% of GDP- 1977-2017

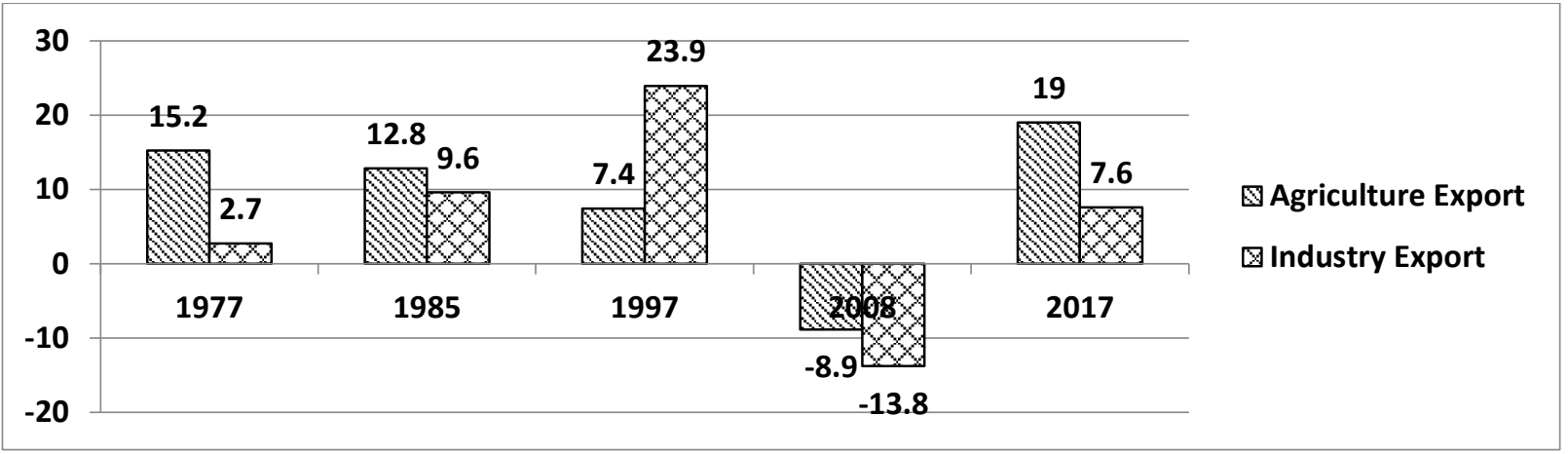

Source: Athukorala \& Jayasuriya, 1994; CBSL, 1997; CBSL 2008; CBSL 2017

Figure 05 demonstrate the changes in export as a percentage of GDP from 1977-2017. The percentage of total export was increased to 19 percent in agriculture in 2017 from 15.2 percent in 1977, while industry export was increased to 7.6 percent in 2017 from 2.7 percent in 1977 . Industry export was increased up to 23.9 per cent in 1997 shows massive increased in industrial sector after 
INTERNATIONAL JOURNAL OF ACADEMIC RESEARCH IN BUSINESS AND SOCIAL SCIENCES Vol. 8, No. 12, Dec, 2018, E-ISSN: 2222-6990 C 2018 HRMARS

new industrial policy. However, due to unrest in the country it was reduced in 2008 , but again shows positive trend in 2017.

Figure 06: GDP in Selected Asian Countries

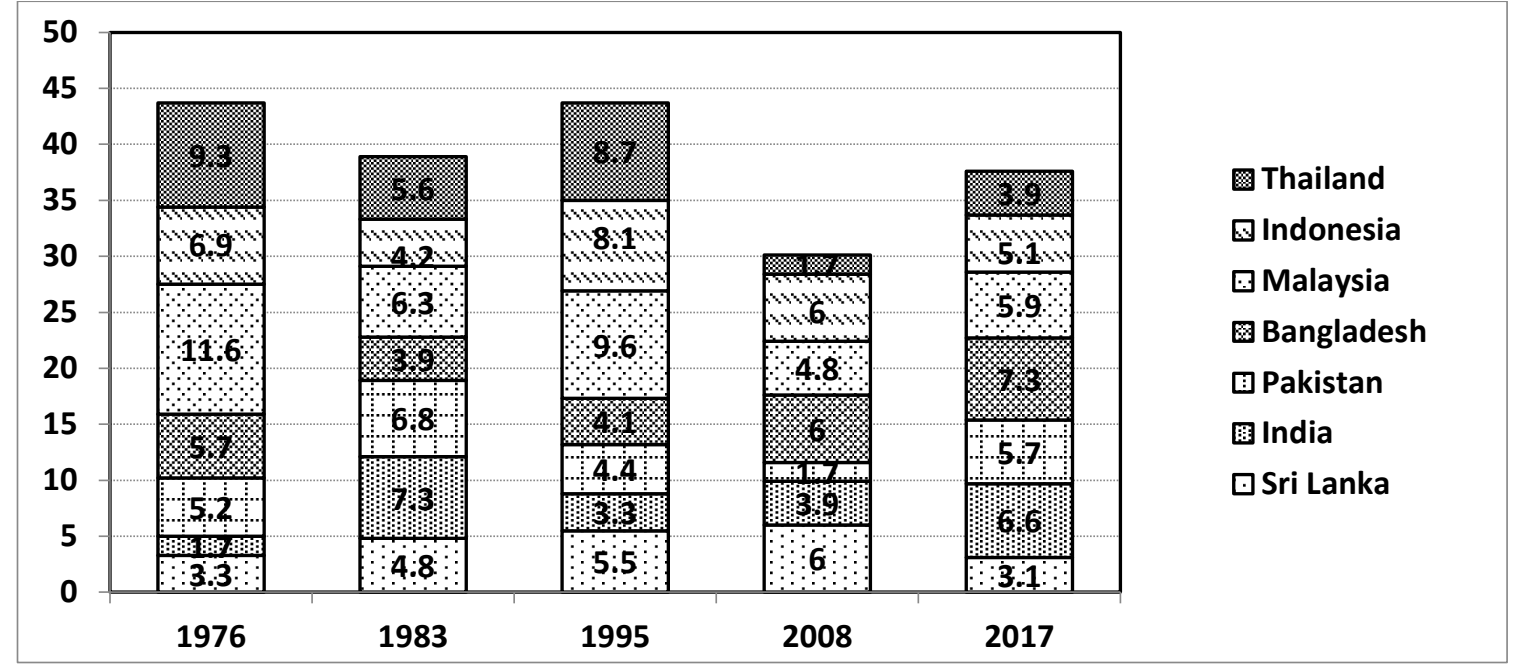

Source: World Bank, 2018

Figure 06 shows GDP annual growth and Figure 07 shows industry annual growth of the selected Asian countries. GDP growth rates shows 3.3 per cent in 1976 increased up to 6 per cent in 2008 and then declined to 3.1 in 2017 as shown in Figure 06. This was only a moderate improvement until 2008 when compared to Indian and Bangladesh. In addition, the annual average growth rate if industry in Sri Lanka shows the lowest in 1983 and second lowest in 2017 among the countries referred in Figure 06. Sri Lanka before introducing export oriented development strategy shown 7.9 annual industry growths as shown in Figure 07. However, in 1983 it was 1.6 and 20173.9 shows that it cannot be considered as an excellent achievement to generate long term growth momentum. Therefore economic performance of Sri Lanka lagged behind that of not only the fast growing economies of Asia, but also that of India, Pakistan and Bangladesh. It is noteworthy that Sri Lanka also adopted it export promotion strategy before its neighboring countries, and implemented trade liberalization policies faster than they are. 
INTERNATIONAL JOURNAL OF ACADEMIC RESEARCH IN BUSINESS AND SOCIAL SCIENCES Vol. 8, No. 12, Dec, 2018, E-ISSN: 2222-6990 @ 2018 HRMARS

Figure 07: Growth Rate of Industry in Selected Asian Countries

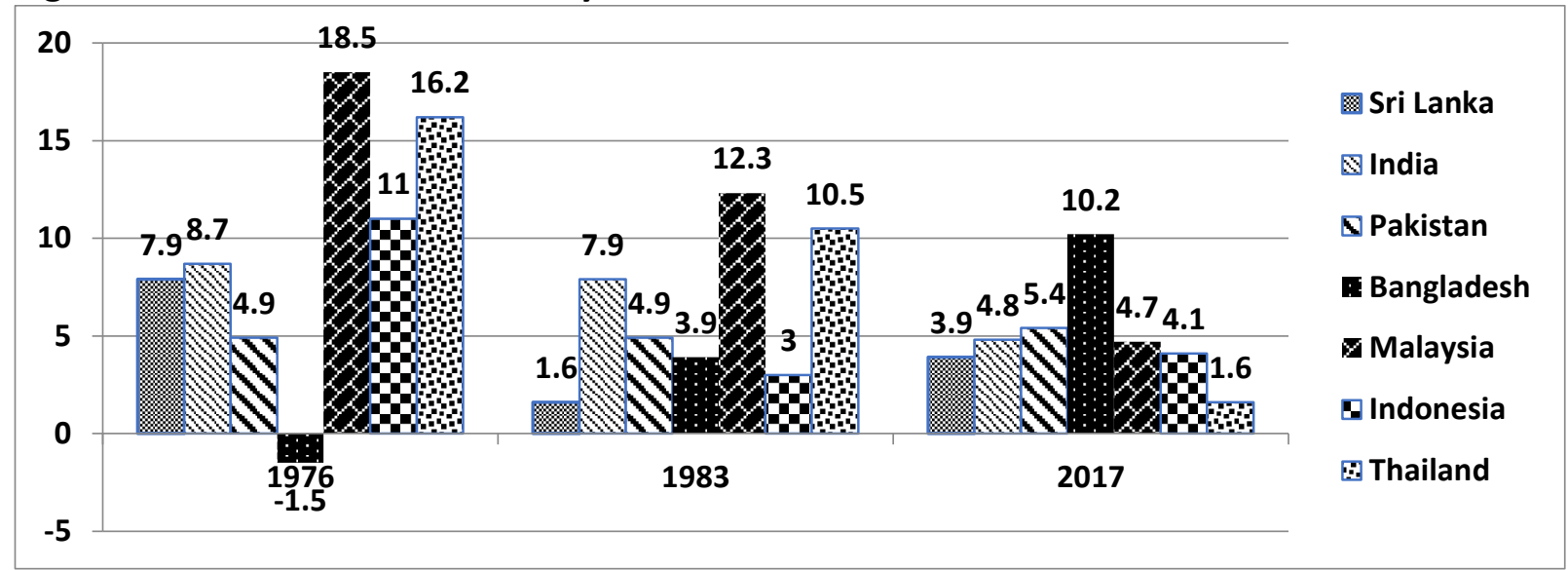

Source: World Bank, 2018

Figure 08: Export Ratios as a \% of GDP

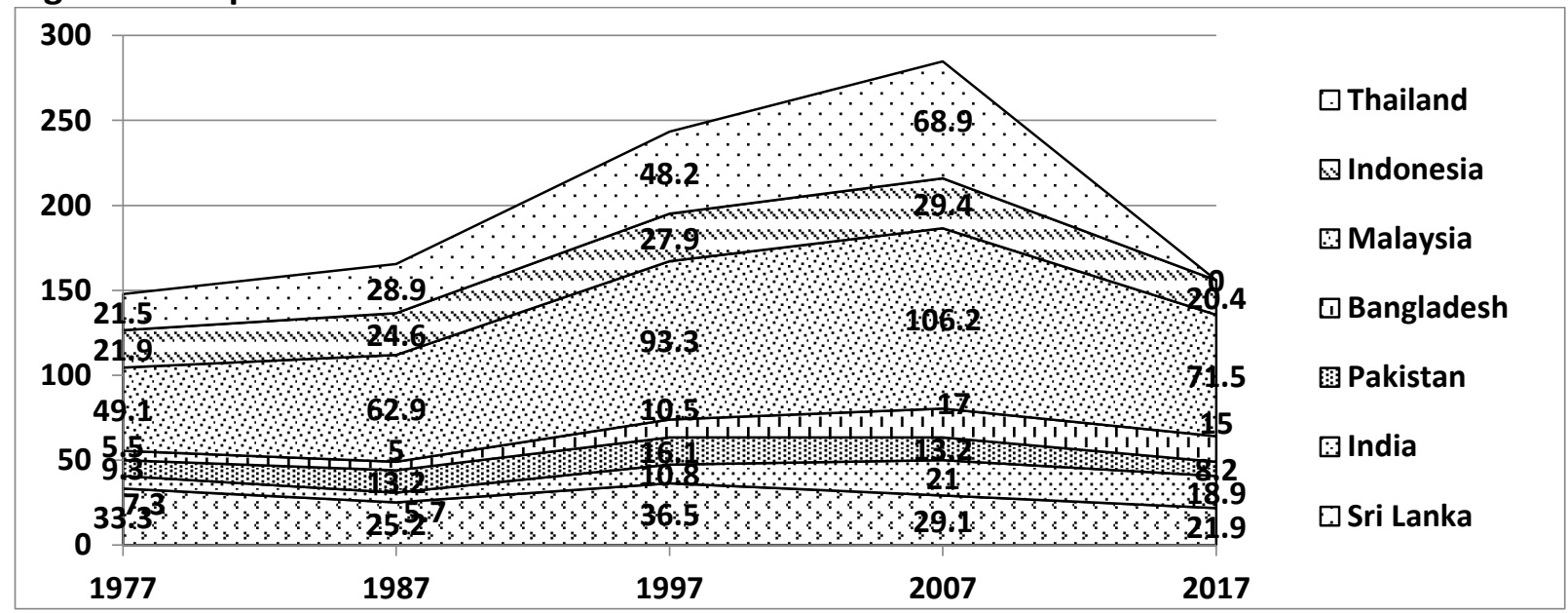

Source: World Bank, 2018

However, Figure 08 shows export to GDP ratios better than comparable to those of Asian economies during these four decades, 1977-2017. In 1977 export ratio was 33.3 per cent comparing to India 7.3, Pakistan 9.3 and Bangladesh 5.5 per cent. In 2017, it was declined to 21.9 per cent in Sri Lanka but comparing with other South Asian countries still keep higher rates.

\section{CHALLENGES AND ISSUES}

As shown in the previous section, since after 1977 industrial policy adopted, there are many structural changes can be identified. Sri Lanka is predominantly an agricultural based country has shifted with the share of manufacturing in the GNP increasing from 9.1 in 1977 to 15.7 percent in 2017, while agriculture sector reducing 6.9 to 2017 from 53.8 in 1977 as shown in Figure 02. However, it is noted that the growth in industrial sector so far has concentrated mainly on labor incentive product such as apparel while global industry changing to high-tech industries. One of the reasons behind this moderate growth was civil war. Country was midst of two civil wars during these four decades. In 1987-89 internal attack from South and up to 2009 Tamil terrorist attack were 
directly affected to foreign investors to invest in high-tech industries which, required high investment. Hence, it is noticed that the growth in the industrial sector has concentrated mainly on labor incentive product such as apparel industry while global industrialization depend on high-tech industries. Under the industrial policy in 1977, Sri Lanka government provides massive benefits to investors. However, the sector is still depended on low-tech industries. After reviewing the trends and challenges, following concerns and obstacles were identified.

Need for Exposure to Institutional Competition: Globally, the trend is towards the adoption of economic liberalization. In Sri Lanka also try to practice global trend, however, some domestic market oriented enterprises tend to resist this process and seek protection and exemptions. Sri Lanka industrial sector has advanced to modest extent in the face of international competition for export orientation (World Bank, 2016).

Industrial Adjustment Program: Over the past four decades, industries have had to adjust themselves in the face of international competition. Some have come through successfully and are now geared to compete effectively in the world markets. Some others have fallen by wayside and have had to close down. Most of these need to be provided a safety net by assisting them. Most of the domestic manufactures are not able to adjust export orientation as a result of lack of knowledge of technology, management etc. (Asian Development Bank, 2017).

Need for Movement towards more Value Added Product: Sri Lanka has noted the satisfactory progress in the adaptation of the industrial sector. However, the growth of manufactured exports have so far in the main exploited only static bases of competitive advantage, such as cheap, semi-skilled or unskilled labor and some natural resources. Export products are thus mainly low value added, low technology and low skill products. There is still heavy dependence on garments based on quotas. There is a need to move away towards more advanced stage products with industries based on competitive advantage. It is need to more encourage domestic as well as foreign investors to invest in large-scale high-tech industries (Central Bank of Sri Lanka, 1997; World Bank, 2016).

Infrastructure Development: Lack of adequate infrastructure is a major bottleneck in industrial advancement. One of the greatest challenges is to provide the infrastructure, particularly in the areas of power, transport and telecommunication. There are vital needs of other facilities such as hotels, hospitals with basic needs and adequate security also should be provided (World Bank, 2016; Asian Development Bank, 2017).

Agriculture Development vs. Industrial Development: As a result of new industrial policy in 1977, agricultural development was neglected. The ultimate result is price acceleration in food products especially rice. The scare earnings therefore earned in a hard way from export would be used to import a large volume of agricultural product from abroad. To achieve desired objectives it is required to finance export income to develop infrastructure facilities and industrial base (World Bank, 2016; Asian Development Bank, 2017).

Productivity Improvement and Skills Development: Productivity improvement and skills development are two key strategies initiatives in industrial policy. In view of the present low level of development in both areas, acceleration of their development will face challenges of considerable magnitude (World Bank, 2016; Asian Development Bank, 2017). 
Land and Labor Market Rigidities: There are certain rigidities imposed through legislative and administrative arrangement in the two areas of land and labor. These are now became an obstacle to the progress of liberalization. Therefore, the socio political imperatives need to be taken into account in the reform of land and labor problems. The need for greater congruity in overall policy in these two areas poses other challenges those needs to address (Asian Development Bank, 2017).

Lack of Support from other Policies: It is clear that industrial policy alone is not sufficient to achieve its desired objectives. In general, Commercial Policy and Exchange Rate policy are more important complementary policy areas of export promotion other than industrial policy (Asian Development Bank, 2017; Pursell \& Ahsan, 2011).

Generally, the issues involved in export expansion are not limited to these concerns. On the other hand issues in industrial policy are not a sole one for problem in export expansion. There are many other factors relating to economic preconditions, institutional support, political culture, state and social commitment and current international environment, affecting the country's export promotion and production process. It should be noted that a study of issues emerging from four decades export expansion and industrialization without reference to these economic, political and social factors is incomplete. Therefore, the focus of this paper was only on the policy areas of industrialization strategy with special reference to export promotion in Sri Lanka.

\section{RECOMMENDATION}

To overcome those barriers, a conceptual model is proposed after considering the causal factors identified throughout this brief study. The proposed model is based on the literature review and analysis of the export expansion issues in Sri Lanka. Indeed, this conceptual model is developed as a recommendation to find out solution for the issues and demonstrate complete and accurate understanding of the present situation. The independent variables are international competition, labor market, skill development, productivity improvement, agriculture development, infrastructure development; value added products and industrial adjustment program. These variables have an indirect effect on public policy for export expansion in Sri Lanka which is the dependent variable. The intervening variables are exchange rates and trade and commerce activities. 
INTERNATIONAL JOURNAL OF ACADEMIC RESEARCH IN BUSINESS AND SOCIAL SCIENCES Vol. 8, No. 12, Dec, 2018, E-ISSN: 2222-6990 @ 2018 HRMARS

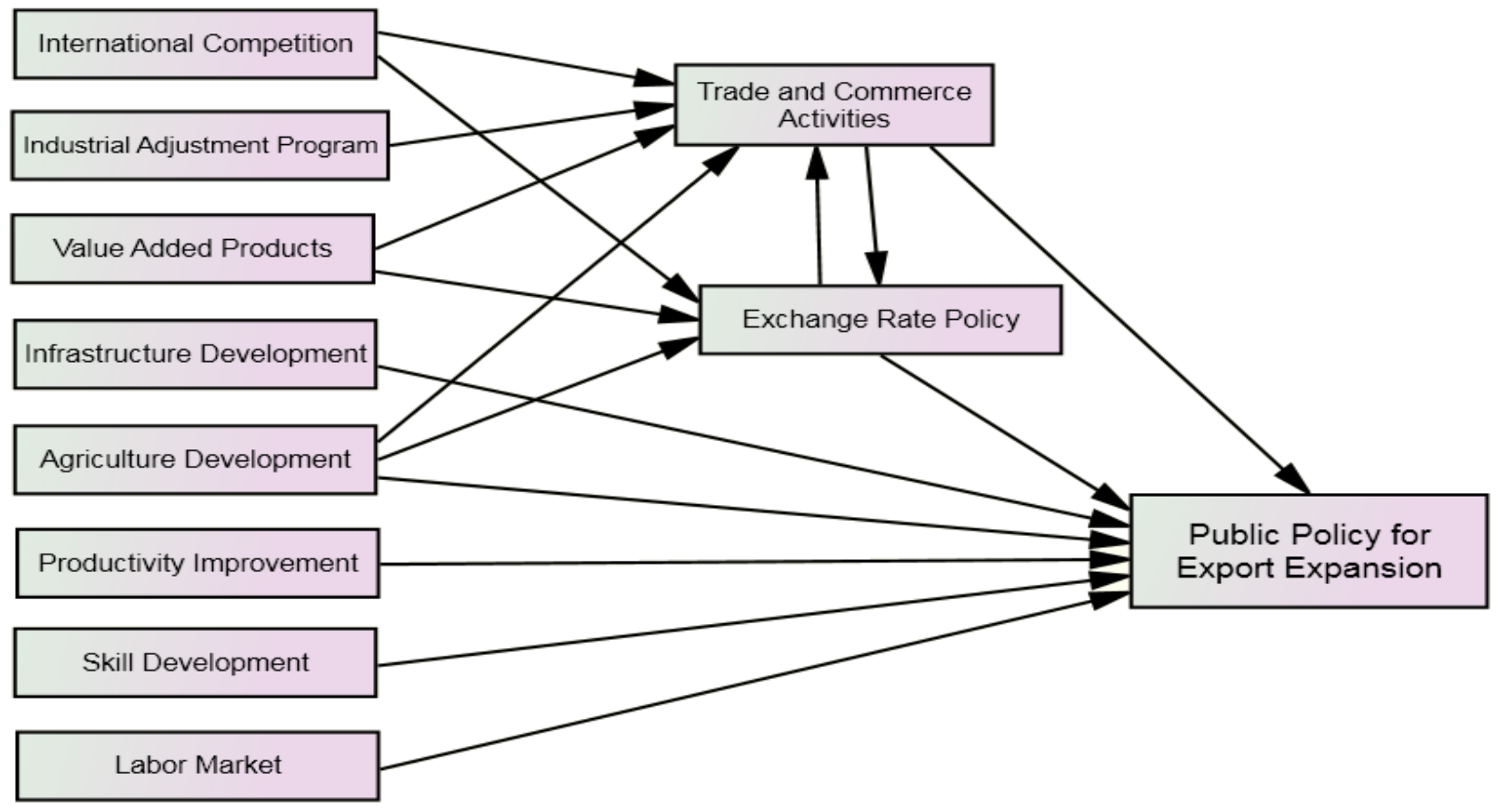

Figure 10: A Propose Model for Export Expansion Policy in Sri Lanka

\section{Logical Relationship between Independent and Dependent Variables}

The causes of export expansion under the industrial policy are mentioned above are explaining how other policy areas affected to the export expansion. These direct casual factors discussed in the paper considered independent variables, because these are the more frequent and more important causes to the export expansion. In fact, these causal factors directly affected to the export expansion. Proposed Model as shown in Figure 10 is suggested how these variables are interrelated. However, trade and commerce activities and exchange rates are function of these primary causes and the results of the export expansion have been anchored. For analysis of this model therefore, it is assumed that those two variables as intervening variables. Most distance causes such as lack of community support, lack of natural resources etc. are not included.

\section{CONCLUSION}

History has proved that it was on the basic of export promotion under the industrialization and state intervention, those countries achieve higher growth in economic development. Over the past four decades of export oriented regime, Sri Lanka was able to push its export promotion in the midst of civil war. Given the continued political unrest of the country, the economic performance based on industrialization appears to be not unsatisfactory. The classical export and import structure has changed and the exports of manufactured production grew significantly. However, export expansion was inadequate to gain economic growth of the country, as compared with the experience of not only fast growing countries in East Asia but also Sri Lanka's neighboring countries like India, Pakistan, and Bangladesh etc. The rate of growth was stagnant around 5 percent level, and subjected to fluctuations during this period. 
Issues involved in industrialization were not limited to industrial policy areas. But these were the areas, which were basically under high degree of control of the government in the short run. Even though government maintains consistency in the industrial policy, the major policy areas of trade strategy, i.e. commercial and exchange policies, the government was unable to maintain consistency throughout the past four decades in providing the required assistance for the export expansion. In addition to the economic growth through industrialization, the government was under pressure to contain rising inflation and civil war expenditure.

However, it is evident that after four decades of experience, Sri Lanka is achieved moderate growth even though unable to maintain the required growth rate to make Sri Lanka a fast growing economy in South Asia. Even though, Sri Lanka has opportunity to grow faster than other South Asian countries because of long term welfarism of the country for free health and education. The welfarism policy already made talented and healthiest citizen comparing other South Asian countries. Being a small economy with a strategic geographical location in Asia, Sri Lanka has apparently a relative advantage to become a fast growing economy with a little effort, which requires a commitment of not only the government, but also the society.

\section{EXPECTED BENEFITS OF THE STUDY}

This study initiates a problem identification process for the government to formulate public policy. It is important to know how private issues become public issues and how it forward to formulate a policy. This study will provide practical experience in coping with a public problem. It will show from where the issue emerged, who is involved in resolving the issue, and how it finally became a public issue. The literature of this study is well grounded in existing data and information of last four decades. Therefore, this study will enable future researchers to have a collection of data and information related industrialization in Sri Lanka. The conceptual framework of this study facilitates the understanding of major factors affecting export expansion in Sri Lanka. Thus, research on the conceptual model might generate practical information. It will be of help to policy makers in setting required policy.

\section{References}

Asian Development Bank. (2017). The Sri Lankan Economy Charting a New Course. (Eds) Athukorala, P., Ginting, E., Hill, H. and Kumar, U., Asian Development Bank, Philippines. http://dx.doi.org/10.22617/TCS178786-2

Athukorala, P. \& Jayasuriya, S. (1994). Macroeconomic Policies, Crises and Growth in Sri Lanka, World Bank Publications, Washington D.C., pp: 20-24.

Athukorala, P. (2014). Growing with Global Production Sharing: The Tale of Penang Export Hub. Competition \& Change, 18(3), pp: 221-245.

Bruton, H.J. (1992). The political Economy of Poverty, Equity and Growth: Sri Lanka and Malaysia, World Bank Oxford University Press, pp: 119-147.

Central Bank of Sri Lanka. (1997). Annual Report. Central Bank Publications, Colombo.

Central Bank of Sri Lanka. (2009). Annual Report. Central Bank Publications, Colombo. https://www.cbsl.gov.lk/sites/default/files/cbslweb_documents/publications/annual_report /2009/en/9_Chapter_05.pdf 
INTERNATIONAL JOURNAL OF ACADEMIC RESEARCH IN BUSINESS AND SOCIAL SCIENCES

Vol. 8, No. 12, Dec, 2018, E-ISSN: 2222-6990 @ 2018 HRMARS

Central Bank of Sri Lanka. (2016). Annual Report. Central Bank Publications, Colombo.

Central Bank of Sri Lanka. (2017). Annual Report. Central Bank Publications, Colombo. https://www.cbsl.gov.lk/sites/default/files/cbslweb_documents/publications/annual_report /2017/en/9_Chapter_05.pdf

Export Development Board. (2016). Industry Capability Report - Sri Lankan Apparel Sector, Export Development Board (EDB), Sri Lanka.

Government of Sri Lanka. (2018). National Export Strategy of Sri Lanka-2022: Electronic and Electrical Components Strategy, https://www.srilankabusiness.com/pdf/nes/sri-lanka-eec-6-web.pdf

Institute of Policy Studies of Sri Lanka. (2012). Sri Lanka: State of the Economy 2010 'Post Conflict Economic Development Challenges' p. 7-8 http://www.ips.lk/talkingeconomics/wpcontent/uploads/2012/09/pb13_Industrial-Development.pdf

Ministry of Finance Sri Lanka. (2016). Budget Speech 2017. http://www.treasury.gov.Ik/article//article-viewer-portlet/render/view/budget-speech-2017.

Pursell, G. and Ahsan, F.M. Z. (2011). 'Sri Lanka's Trade Policies: Back to Protectionism', Australia South Asia Research Centre Working Paper 2011/03, Canberra: Australian National University.

Rajapakshe, W. (2018). An Analysis of Major Factors Affecting Labor Turnover in the Apparel Industry in Sri Lanka: Policy Alternations for Solving the Problem. International Journal of Academic Research in Economics and Management Sciences, 7(3), 214-231.

Thomas R Dye. (1978). Understanding Public Policy, $3^{\text {rd }}$ ed. Englewood Cliff NJ, Prentice Hall.

UNIDO (United Nations Industrial Development Organization). (1995). Country Industrial Development Profile of Sri Lanka. Industrial Center for Industrial Studies, United Nations Industrial Development Organization, pp: 28-32.

Widyantha, W.G.S. (1997). Industrialization, what went wrong?, Economic Review. People's Bank Publications, pp: 2 -3.

World Bank. (1984). Sri Lanka: Recent Economic Development Prospects and Policies, Report No. 5038-CE, Washington D.C.

World Bank. (2016). Enhancing competitiveness in Sri Lanka. World Bank Group, Washington D.C., PP:14-38.

World Bank. (2018). World Bank national accounts data, and OECD National Accounts data files. https://data.worldbank.org/indicator/ny.gdp.mktp.kd.zg?end=2017\&start=1978\&view=char $\mathrm{t}$

\section{Acknowledgement}

The authors acknowledge the support provided by the Sri Lanka Institute of Information technology (SLIIT) Sri Lanka for carrying out the research work. The author also is highly thankful to the panels and anonymous reviewers and editors for valuable and on earlier version of this manuscript.

\section{Corresponding Author}

Wasantha Rajapakshe, Senior Lecturer (Higher Grade), SLIIT Business School, Sri Lanka Institute of Information Technology, Sri Lanka.

Email: wasantha.r@sliit.lk 